\title{
Utilisation and Quality Management of Power Plant Fly
}

\section{Ash}

\author{
M. AMBRUS ${ }^{1}$, R. SZABÓ ${ }^{2}$, G. MuCSI ${ }^{3}$ \\ 1University of Miskolc, Faculty of Earth Science and Engineering, Institute of Raw Material Preparation and \\ Environmental Processing, maria.ambrus@uni-miskolc.hu \\ ${ }^{2}$ University of Miskolc, Faculty of Earth Science and Engineering, Institute of Raw Material Preparation and \\ Environmental Processing, ejtszabor@uni-miskolc.hu \\ ${ }^{3}$ University of Miskolc, Faculty of Earth Science and Engineering, Institute of Raw Material Preparation and \\ Environmental Processing, ejtmucsi@uni-miskolc.hu
}

\begin{abstract}
Over the past decades, both the residential and industrial energy demand has increased due to the continuously growing consumption and production. As a large share of the electricity is still produced using fossil fuels, the utilisation of the by-products is a contemporary and pervasive issue. Fly ash is generated in large quantities in coal-fired power plants and has been proven to be an appropriate raw material for various industrial uses. Among others, it is applicable as an additive and lightweight aggregate in the cement and concrete industry, can be used for $\mathrm{CO}_{2}$ sequestration, glass foam production, catalyst production, or as a base material for geopolymers, as well. Geopolymers are inorganic polymers produced via the reaction between solid alumina and silica containing or alkali silicate materials in alkali media. Due to their numerous advantageous properties and wide variety of utilisation possibilities, research on fly ash base geopolymers became widespread topic. The quality of fly ash is determined by technical requirements, and the degree of quality control requirements depends on the final use. In certain fields of applications, standards and regulations have already been created to ensure the consistent quality of the final products made from fly ash, e.g. in the cement and concrete industry. There are various methods for fly ash processing, however, the methods to achieve the necessary properties are not standardised.
\end{abstract}

Keywords: geopolymer, power plant fly ash, recycling, quality management

\section{Introduction}

As part of the continuous contemporary attempts for $\mathrm{CO}_{2}$ emission reduction, many international organisations and countries emphasise not only the use of the best available technology in power plants, but the possibility of reduction and complete phase-out of coal in the upcoming years. After the decrease in coal consumption, a recurrent rise can be observed in the last few years due to the economic growth in Asian countries like China or India [1]. In the European Union, solid fuels take up $19 \%$ on average, as it is illustrated in Figure 1. However, the sources of energy production differ in the member states, with solid fuels being the main source of energy in Poland with 79\%, Estonia with 73\% and Greece with 61\% share in the energy mix of each country [2]. 
In the coal-fired power plants, fly ash is separated from the flue gas using electrostatic precipitators, as a solid residue. The major components are $\mathrm{SiO}_{2}$ and $\mathrm{Al}_{2} \mathrm{O}_{3}$, with other minor components being $\mathrm{Fe}_{2} \mathrm{O}_{3}$, $\mathrm{TiO}_{2}, \mathrm{CaO}, \mathrm{MgO}, \mathrm{K}_{2} \mathrm{O}$, and $\mathrm{Na}_{2} \mathrm{O}$. Considering its morphology, fly ash is usually composed of mostly fine spherical particles, the median particle size ranging between 10 and $100 \mu \mathrm{m}$. Based on chemical composition, two types can be distinguished: class $\mathrm{F}$ ashes primarily consist of calcium aluminosilicate glass, quartz, tricalcium aluminate, and free lime ( $\mathrm{CaO}$ ), while class $\mathrm{C}$ fly ash is a high calcium fly ash, containing more than $20 \% \mathrm{CaO}$. However, the chemical composition and physical properties can vary significantly because of variations in the operation system of the power plant, the coal sources, and even due to the method and type of landfilling or storage $[3,4,5]$.

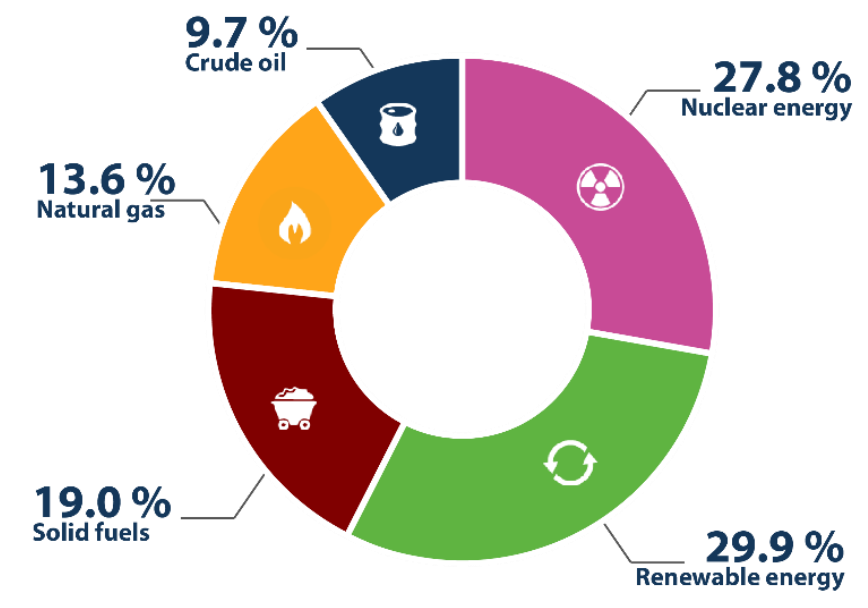

Figure 1. Energy production by source in the EU in 2017 [2]

In the article, the main utilisation methods are reviewed, along with some of the quality management methods and standards applied during the possible utilisations.

\section{Fly ash utilisation}

The generation of power plant fly is reported to be around 750 million tons per year worldwide. On a worldwide average, around $25 \%$ of the generated fly is utilised, for example for soil amendment, in the building industry, for the production of ceramics, catalysts, adsorbents etc., and concrete production takes up around $20 \%$ of this share [4]. In case of the European Union, India and the USA, the consumption of fly ash is higher than the worldwide average, with $90 \%, 60 \%$ and $50 \%$, respectively [4]. With the use of fly ash with high fineness and low carbon, the water demand of concrete can be reduced, without changing the workability. The setting time of concrete can also be delayed with higher-calcium fly ashes, which results in longer curing time. If the necessary curing is provided, the long-term compressive strength of concrete can be improved, compared to Portland cement concrete $[4,6]$.

Another use of fly ash in the construction industry is the production of lightweight aggregate. Both class $\mathrm{C}$ and class $\mathrm{F}$ fly ash can be used as lightweight aggregate replacement, processed by milling, microwave radiation or sintering. Some of the advantages are the increased strength/weight ratio 
(because of the pozzolanic reaction of fly ash), improved thermal and sound insulation and fire resistance properties $[7,8]$.

Traditionally, fine-grained soils are not considered suitable for construction and are replaced with soil with better properties. However, using fly ash for the stabilisation of such soils provides not only a less expensive method, but the use of industrial by-product provides a more environmentally friendly solution. Some properties of fly ash stabilised soil that make the geotechnical application possible are:

- decrease in swelling shrinkage and plasticity potential,

- improved compressive and tensile strength,

- good performance on durability tests,

- decreased permeability,

- improved transfer properties $[9,10]$

Fly ash can be used as an alternative source of feedstock for $\mathrm{CO}_{2}$ sequestration, using the calcium oxide to be reacted with $\mathrm{CO}_{2}$ to form stable carbonates. Its use is advantageous as it has low cost, high reactivity, and available near $\mathrm{CO}_{2}$ emission sources. $\mathrm{CO}_{2}$ can be captured with fly ash by adsorption and carbonation. In case of carbonation, temperature, pressure and $\mathrm{H}_{2} \mathrm{O}$ are the key factors in the sequestration process. With optimised parameters, approximately $60 \mathrm{~g} \mathrm{CO}_{2} / \mathrm{kg}$ fly ash sequestration capacity can be achieved $[11,12]$.

Geopolymers are promising advanced materials with rapid worldwide development in the past years, that have the potential to substitute the traditional Portland cement and which can be used in various fields of industrial applications. Prepared via the reaction between solid alumina and silica containing or alkali silicate materials, such as metakaolin, fly ash, blast furnace slag or red mud, in alkali media, geopolymers have numerous advantages: good mechanical strength, acid and fire resistance, environmental sensitivity, low price and permeability in comparison with Portland cement $[13,14$, 15].

Fly ash-based geopolymers prepared at room temperature have a practical significance for in-situ pouring for the cement and concrete industry, and results in energy reduction [15]. With the addition of lightweight aggregates, e.g. silica fume, pumice, expanded perlite etc., lightweight fly ash based geopolymer concrete can be produced, with reduced seismic risks, increased fire resistance and easier transportation $[13,16,17]$. Geopolymers have been proven to be adequate adsorbents for wastewater treatment. Fly-ash based geopolymers are suitable for the removal of anionic surfactant sodium dodecyl benzene sulfonate, copper ions and fecal coliforms as well $[18,19,20]$. Using fly ash based geopolymer as binder and expanded polystyrene, a composite insulating material (Figure 2) can be prepared. However, with increasing fly ash quantity, the resulting thermal conductivity increases, as well [21]. 


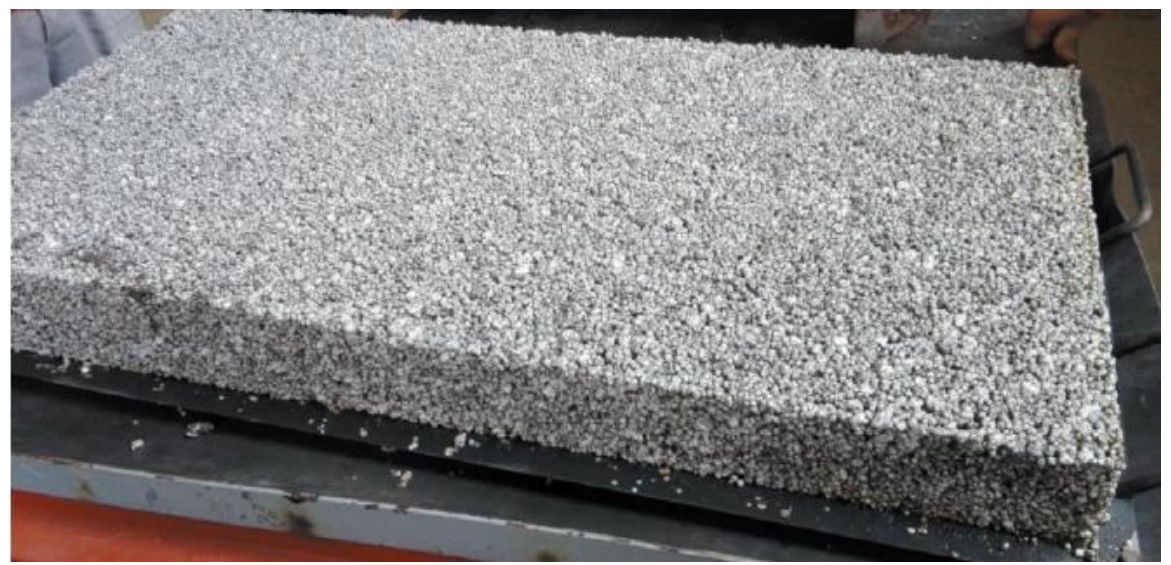

Figure 2. A geopolimer-EPS composite specimen [21]

Other possible applications of fly ash include the production of fly ash foam glass as insulation material [22, 23], porous catalysts [4], hydraulic road binders [24] or proppant for oil and gas wells [25].

\section{Quality management of fly ash utilisation}

If some properties of fly ash are not appropriate (particle size distribution, specific surface area, reactive silica, high $\mathrm{LOI}$ or $\mathrm{SO}_{3}$ ) for a given use, it can have negative effect on the final product. For this reason, many standards have been adopted to assure the performance of the products, containing the definitions and necessary properties of fly ash. For example, in case of the use in cement and concrete production, several standards have been created that define the chemical and physical requirements of fly ash to meet:

- EN 450-1 in Europe [26],

- ASTM C 618 in the USA [27],

- AZ/NZS 3582 in Australia and New Zealand [28],

- JIS 6201 in Japan [29],

- IS 3812-1 in India [30],

- GB/T 1596 in China [31],

- GOST 25818 in Russia [32],

- $\quad$ MSZ EN 450-1:2013 in Hungary [33].

For fly ash, some of the main properties that are determined in most standards are particle fineness, water demand, reactivity with lime or in mortars (activity index) setting time and the proportion of its main oxides $\left(\mathrm{SiO}_{2}, \mathrm{Al}_{2} \mathrm{O}_{3}\right.$ and $\left.\mathrm{Fe}_{2} \mathrm{O}_{3}\right)$ [1].

The possibility to use lower quality and deposited fly ash has become a widespread concept in the past years, which can be a challenging task due to the poor reactivity or the changes in the mineralogy and microstructure of the fly ash [34]. Considering that particle fineness and reactivity are important factors determining the applicability of fly ash, various methods have been tested to modify these properties, making the utilisation of fly ash more feasible. Increased proportion of coarse particle can 
decrease the reactivity of fly ash. Thus, to achieve the necessary particle size range determined in the given standard, screening, air classification or grinding of the base material can be used [5].

Screening is the simplest approach for fly-ash processing which can enhance reactivity by separating the coarse particles and foreign matters. The effect of screening can be observed in Figure 3. For dry screening, 45 and $63 \mu \mathrm{m}$ sieves are the most commonly used, and still economical sieve sizes [5, 35]. Air classification provides particle separation size and density and may be performed for the removal of coarse particles or for the selective concentration of finer particle size. Via particle size control methods, the unburned carbon content of the fly ash can be decreased, too, the high quantity of which may also hinder fly ash utilisation. Other methods for unburned coal separation can be gravity and electrostatic separation, froth flotation and oil agglomeration [5, 35, 36, 37].

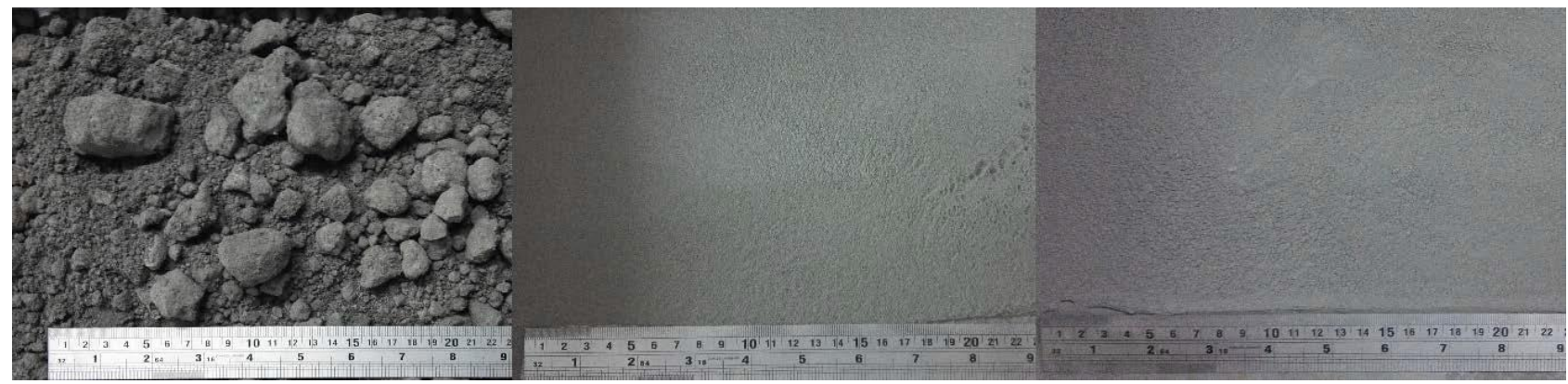

Figure 3. Images of raw (left), and sieved < $600 \mu \mathrm{m}$ (centre) and < $63 \mu \mathrm{m}$ (right) fly ash samples [36]

Grinding provides a method to reduce particle size and increase specific surface area, and it is a commonly used technique in the cement industry. During grinding, many operating and machine parameters (mill velocity, grinding media size, material, ...) should be optimised to achieve the desired results in fly ash fineness. Most applications and researches focused on ball milling of fly ash, as during grinding, micro and even nano crystalline particles can be produced with a simple and comparatively inexpensive grinding technique $[35,38]$.

In case of geopolymer production, the mechanical activation of fly ash via grinding is also a crucial issue, as grinding in different types of mills can result in geopolymers with different mechanical and structural properties. Furthermore, the determination of optimal grinding time is also necessary for geopolymer production, as exceeding the optimum results in decreased compressive strength. The agglomeration of particles and/or decrease in surface area due to excessive grinding time has been observed, negatively affecting the mechanical properties $[39,40]$.

However, depending on the type of fly ash used, the processing may be two-fold, using the combination of initial separation and then grinding to get the highest amount and quality base material [38].

\section{Summary}

As part of the growing population and consumer demand, the utilisation of wastes and by-products can be a crucial issue in the near future. This issue has been realised by several industrial fields, and the use of industrial by-products, such as fly ash has become more and more widespread. Taking 
advantage of its beneficial properties, various construction materials and additives, catalysts, soil supplementary materials, and even environmentally friendly materials can be produced from fly ash. Because of the variable chemical and physical properties of fly ashes, many standards have been created to assure the quality of the final products, which properties can be achieved via different processes.

\section{Acknowledgement}

The described work/article was carried out as part of the „Sustainable Raw Material Management Thematic Network - RING 2017", EFOP-3.6.2-16-2017-00010 project in the framework of the Széchenyi 2020 Program. The realization of this project is supported by the European Union, cofinanced by the European Social Fund.

\section{References}

[1] H-J. Feuerborn - D. Harris - C. Heidrich (2019) Global Aspects on Coal Combustion Products. EUROCOALASH 2019 Proceedings, pp. 1-17.

[2] Eurostat (2019) Shedding light on energy in the EU - A guided tour of energy statistics. https://ec.europa.eu/eurostat/cache/infographs/energy/bloc-2b.html

[3] B. Balagurumurthy - R. Singh - T. Bhaskar (2015) Catalysts for Thermochemical Conversion of Biomass. Recent Advances in Thermo-Chemical Conversion of Biomass, pp. 109-132.

[4] S. Mostafa Hosseini Asl - A. Ghadi - M. Sharifzadeh Baei - H. Javadian - M. Maghsudi - H. Kazemian (2018). Porous catalysts fabricated from coal fly ash as cost-effective alternatives for industrial applications: A review. Fuel, 217, pp. 320-342.

[5] U.S. Department of Transportation Federal Highway Administration (2017) Fly Ash Facts for Highway Engineers. https://www.fhwa.dot.gov/pavement/recycling/fach00.cfm

[6] T. Michael (2007). Optimizing the Use of Fly Ash in Concrete. https://www.cement.org/docs/default-source/fc_concrete_technology/is548-optimizing-theuse-of-fly-ash-concrete.pdf

[7] S. Sambuunyam - S. Pareek - S. Danzandorj - B-E. Purev-Erdene - R. Thombare (2019). Study on Utilization of Fly Ash in Production of Lightweight Aggregate. In: M. J. McCarthy - M. D. Newlands - M. R. Jones - T. D. Dyer - L. J. Csetenyi - L. Zheng (eds.) EuroCoalAsh 2019 Proceedings. pp. 196-206.

[8] M. Franus - R. Panek - J. Madej - W. Franus (2019) The properties of fly ash derived lightweight aggregates obtained using microwave radiation. Construction and Building Materials, 227, 116677.

[9] A. Patel (2019). Soil stabilization. Geotechnical Investigations and Improvement of Ground Conditions, pp. 19-27. 
[10] I. Nawaz (2013). Disposal and utilization of fly ash to protect the environment. International Journal of Innovative Research in Science, Engineering and Technology, 2(10), pp. 5259-5266.

[11] W. Liu - S. Sheng - K. Xu - Q. Chen - J. Xu - Z. Sun - Y. Wang - S. Hu - X. Wang - Y. Yue - J. Xiang (2018). $\mathrm{CO}_{2}$ sequestration by direct gasesolid carbonation of fly ash with steam addition. Journal of Cleaner Production, 178, pp. 98-107.

[12] L. Ji - H. Yu - B. Yu - K. Jiang - M. Grigore - X. Wang - S. Zhao - K. Li (2018). Integrated absorption-mineralisation for energy-efficient $\mathrm{CO}_{2}$ sequestration: Reaction mechanism and feasibility of using fly ash as a feedstock. Chemical Engineering Journal, 352, pp. 151-162.

[13] A. Top - H. Vapur - M. Altiner - D. Kaya - A. Ekicibil. (2019). Properties of fly ash-based lightweight geopolymer concrete prepared using pumice and expanded perlite as aggregates. Journal of Molecular Structure, 127236.

[14] X. Zhao - C. Liu - L. Wang - L. Zuo - Q. Zhu - W. Ma (2019). Physical and mechanical properties and micro characteristics of fly ash-based geopolymers incorporating soda residue. Cement and Concrete Composites, 98, pp. 125-136.

[15] B. S. Mohammed - S. Haruna - M. M. A. Wahab - M. S. Liew - A. Haruna (2019) Mechanical and microstructural properties of high calcium fly ash one-part geopolymer cement made with granular activator. Heliyon, 5(9), e02255.

[16] E. Yasar - C. D. Atis - A. Kilic (2004). High Strength Lightweight Concrete Made with Ternary Mixtures of Cement-Fly Ash-Silica Fume and Scoria as Aggregate. Turkish Journal of Engineering and Environmental Sciences, 28, pp. 95-100.

[17] H. A. Mboya - K. N. Njau - A. L. Mrema - C. K. King'ondu (2019). Influence of scoria and pumice on key performance indicators of Portland cement concrete. Construction and Building Materials, 197, pp. 444-453.

[18] A. A. Siyal - M. R. Shamsuddin - N. E. Rabat - M. Zulfiqar - Z. Man - A. Low (2019). Fly ash based geopolymer for the adsorption of anionic surfactant from aqueous solution. Journal of Cleaner Production, 229, pp. 232-243.

[19] M. S. Al-Harahsheh - K. Al Zboon - L. Al-Makhadmeh - M. Hararah - M. Mahasneh (2015). Fly ash based geopolymer for heavy metal removal: a case study on copper removal. Journal of Environmental Chemical Engineering, 3, pp. 1669-1677.

[20] M. Jo - L. Soto - M. Arocho - J. St John - S. Hwang (2015). Optimum mix design of fly ash geopolymer paste and its use in pervious concrete for removal of fecal coliforms and phosphorus in water. Construction and Building Materials, 93, pp.1097_1104.

[21] T. Magyar - J. Faitli- R. Szabó. (2017) Geopolimer-EPS kompozit szigetelő anyagok eredő hővezetési tényezőjének elméleti és kísérleti vizsgálata. Építőanyag - Journal of Silicate Based and Composite Materials, 69(3), pp. 74-82. 
[22] B-E. Purev-Erdene - S. Pareek - S. Danzandorj - S. Sambuunyam - R. Thombare (2019). Use of Fly Ash in Production of Foam Glass. In: M. J. McCarthy - M. D. Newlands - M. R. Jones - T. D. Dyer - L. J. Csetenyi - L. Zheng (eds.) EuroCoalAsh 2019 Proceedings. pp. 207-214.

[23] J. Lia - X. Zhuang - E. Monfort - X. Querol - A. S. Llaudis - O. Font - N. Moreno - F. J. G. Ten - M. Izquierdo (2018) Utilization of coal fly ash from a Chinese power plant for manufacturing highly insulating foam glass: Implications of physical, mechanical properties and environmental features. Construction and Building Materials, 175, pp. 64-76.

[24] F. Kresta (2019). Hydraulic Road Binders with High Content of Fly Ash: Czech Experience. In: M. J. McCarthy - M. D. Newlands - M. R. Jones - T. D. Dyer - L. J. Csetenyi - L. Zheng (eds.) EuroCoalAsh 2019 Proceedings. pp. 165-174.

[25] T. Robl - A. Oberlink - T. Duvallet - R. Jewell - L. Ring - R. L. Cook (2019). Use of Fly Ash as a Proppant in Clean Fracking Unconventional Oil and Gas Wells. In: M. J. McCarthy - M. D. Newlands - M. R. Jones - T. D. Dyer - L. J. Csetenyi - L. Zheng (eds.) EuroCoalAsh 2019 Proceedings. pp. 107-114.

[26] EN 450-1: Fly ash for concrete - Part 1: Definition, specifications and conformity criteria, 2012

[27] ASTM C 618-171: Standard Specification for Coal Fly Ash and Raw or Calcined Natural Pozzolan for Use in Concrete, 2017

[28] AS/NZS 3582.1: Supplementary cementitious materials, Part 1: Fly ash, 2016

[29] JIS 6201: Fly ash, 1991

[30] IS 3812-1: Pulverized Fuel Ash - Specification, Part 1 For use as Pozzolana in Cement, Cement Mortar and Concrete, 2003

[31] GB/T 1596: Fly ash for cement and concrete, 2017

[32] GOST 25818-91: Thermal plant fly-ashes for concrete, 1991

[33] MSZ EN 450-1:2013: Pernye betonhoz. 1. rész: Fogalommeghatározások, követelmények és megfelelöségi feltételek, 2013

[34] M. B. Yeheyis - J. Q. Shang- E.K. Yanful, E K. (2009). Chemical and Mineralogical Transformations of Coal Fly Ash after Landfilling, Presentation, World of Coal Ash Conference (WOCA), May 4-7, 2009. Lexington, Kentucky, USA

[35] M. J. McCarthy - L. Zheng - R. K. Dhir - G. Tella, G. (2018). Dry-processing of long-term wet-stored fly ash for use as an addition in concrete. Cement and Concrete Composites, 92, pp. 205-215.

[36] T. A. Hope - M. J. McCarthy - L. J. Csetenyi (2019). Wet Stored Fly Ash: Processing for Use as an Addition in Concrete. In: M. J. McCarthy - M. D. Newlands - M. R. Jones - T. D. Dyer - L. J. Csetenyi - L. Zheng (eds.) EuroCoalAsh 2019 Proceedings. pp. 453-466.

[37] Y. Xing - F. Guo - M. Xu - X. Gui - H. Li - G. Li - Y. Xia - H. Han (2019). Separation of unburned carbon from coal fly ash: A review. Powder Technology, 353, pp.372-384. 
International Journal of Engineering and Management Sciences (IJEMS) Vol. 4. (2019). No. 4

DOI: 10.21791/IJEMS.2019.4.37.

[38] A. Peterová - F. Škvára - M. Šídlová - R. Šulc - K. Sokolová - R. Snop (2019). Can Czech Stockpiled Fly Ash be Used in the Production of Concrete? In: M. J. McCarthy - M. D. Newlands - M. R. Jones T. D. Dyer - L. J. Csetenyi - L. Zheng (eds.) EuroCoalAsh 2019 Proceedings. pp. 123-130.

[39] G. Mucsi - S. Kumar - B. Csőke - R. Kumar - Z. Molnár - Á- Rácz - F. Mádai - Á. Debreczeni, (2015). Control of geopolymer properties by grinding of land filled fly ash. International Journal of Mineral Processing, 143, pp- 50-58.

[40] S. Kumar - R. Kumar (2011). Mechanical activation of fly ash: effect on reaction, structure and properties of resulting geopolymer. Ceramics International, 37, pp. 533-541. 